\title{
Spatial variability of enthalpy in rabbit house with and without ridge vent
}

\author{
Patrícia F. P. Ferraz ${ }^{1}$, Gabriel A. e S. Ferraz ${ }^{1}$, Flavio A. Damasceno ${ }^{1}$, \\ Raquel S. de Moura ${ }^{2}$, Maria A. J. G. Silva ${ }^{1} \&$ Rodrigo de L. Rodrigues ${ }^{3}$ \\ ${ }^{1}$ Universidade Federal de Lavras/Departamento de Engenharia. Lavras, MG. E-mail: patricia.ponciano@deg.ufla.br (Corresponding author) - ORCID: \\ 0000-0002-9708-0259; gabriel.ferraz@deg.ufla.br - ORCID: 0000-0001-6403-2210; flavio.damasceno@deg.ufla.br - ORCID: 0000-0002-8284-7496; \\ alicejunqueira.6@gmail.com - ORCID: 0000-0001-7872-7283 \\ ${ }^{2}$ Universidade Federal de Lavras/Departamento de Zootecnia/Setor de Cunicultura. Lavras, MG. E-mail: raquelmoura@dzo.ufla.br - ORCID: 0000-0002- \\ 9642-1779 \\ ${ }^{3}$ Universidade Federal de Lavras/Departamento de Zootecnia. Lavras, MG. E-mail: rodrigolimadomingos95@hotmail.com - ORCID: 0000-0002-1107-9063
}

\begin{abstract}
The profitability of a rabbit farming system must consider the rabbit's breed, nutrition, management, sanitation and mainly the thermal environment that the animal will be exposed during the productive period. The aim of this study was to compare the internal thermal environment of two rabbit houses, one with ridge vent and the other without ridge vent. Geostatistical technique was used to evaluate the spatial variability of enthalpy. Data were collected at 48 points in each house during eight days at the end of summer season 2016. Measurements of dry-bulb temperature, relative humidity and wind speed were made for $1 \mathrm{~min}$ at three times a day at 7:00 a.m., 12:00 a.m. and 5:00 p.m. In addition, the enthalpy was calculated and a data analysis was performed using geostatistical tools and isocolor maps through interpolation by kriging. Based on results from geostatistics, it was possible to characterize the variability magnitude and structure of this variable inside the rabbits' houses with and without ridge vent. The heterogeneity of the spatial distribution of enthalpy in several regions of two houses was also observed through generated isocolor maps. The ridge vent assisted in obtaining a more favorable internal environment for rabbit breeding because this house showed more comfortable conditions of enthalpy values, besides lower heterogeneity of the spatial distribution of enthalpy.
\end{abstract}

Key words: ambience, welfare, rabbit breeding, geostatistics, mapping

\section{Variabilidade espacial da entalpia em galpão para coelhos com e sem lanternim}

RESUMO: Para que um sistema de produção de coelhos seja rentável, deve-se levar em consideração a raça do coelho, nutrição, manejo, sanidade e, principalmente, ambiente térmico que o animal ficará exposto durante o período produtivo. O objetivo deste trabalho foi comparar o ambiente térmico interno em dois galpões de criação de coelhos, sendo um galpão sem lanternim e outro galpão com lanternim por meio da geoestatística. Foram coletados dados em 48 pontos em cada galpão, durante oito dias do final do verão de 2016. As medições de temperatura do bulbo seco, umidade relativa do ar e velocidade do vento foram feitas durante um minuto, em três horários do dia, às 7, 12 e 17 h. Posteriormente, calculou-se a entalpia e realizou-se uma análise dos dados utilizando as ferramentas da geoestatística e a confecção de mapas de isocores por meio da interpolação por krigagem. Com base nos resultados da geoestatística foi possível caracterizar a magnitude e a estrutura da variabilidade dessa variável no interior dos galpões sem e com laternim. Observou-se ainda, por meio dos mapas de isocores confeccionados, a heterogeneidade da distribuição espacial da entalpia em diversas regiões dos dois galpões. O lanternim auxiliou na obtenção de ambiente interno mais favorável para criação de coelhos devido ao fato deste galpão apresentar valores de entalpia mais próximos das condições consideradas como ideais para o alojamento de coelhos, além de menor heterogeneidade na distribuição espacial da entalpia.

Palavras-chave: ambiência, bem-estar, cunicultura, geoestatística, mapeamento

Ref. 189175 - Received 15 Dec, 2017 • Accepted 19 Oct, 2018 • Published 16 Jan, 2019 


\section{INTRODUCTION}

World production of rabbit meat in 2014 reached over $1,600,000$ tons, where Asia stood out as the largest producer region, with $58.9 \%$ of total world production, followed by Europe (33.5\%) and Africa (6.1\%) (FAOSTAT, 2017). In Brazil, the consumption of rabbit meat is still small in relation to other countries, especially in Europe (Machado, 2015). However, such activity shows great growth potential, since it makes possible the meat production of high nutritional value and excellent quality skin with low investment. Rabbit is considered as specie with easy management, high growth, customizable feeding and have a great potential for meat production in developing countries, such as Brazil, which is expected to increase production in the next years (Machado, 2015).

According to Jaruche et al. (2012), for a good productive performance, rabbits over 20 to 30 days of life should be subjected to an ideal temperature, between 15 and $25{ }^{\circ} \mathrm{C}$ and relative humidity between 60 and $70 \%$ (Ferreira et al., 2012). Based on these environmental information, the enthalpy $(\mathrm{H})$ can be calculated. The $\mathrm{H}$ is a thermodynamic property that can be used to evaluate thermal environment for animals, considering the meteorological variables that most influence the animal's thermal comfort, the dry-bulb temperature and the relative humidity (Rodrigues et al., 2010). In order to improve the thermal comfort inside the facilities, techniques of environmental modifications can be used, for example the use of ridge vent in the house roofing to provide natural ventilation and lighting of environments.

The thermal variables inside the installation must be homogeneous in order to potentiate the production performance evaluated through spatialization (Yanagi Junior et al., 2011). In this context, this study aims to characterize and compare the thermal environment of two rabbit houses, one with ridge vent (WRV) and the other without ridge vent (NRV) through spatial distribution of $\mathrm{H}$ using isocolor maps generated from interpolation by kriging.

\section{Material and Methods}

The experiment was performed in the Sector of Rabbit breeding of the Department of Animal Science of the Universidade Federal de Lavras, Minas Gerais, Brazil (21 ${ }^{\circ} 14^{\prime}$ $\mathrm{S}, 45^{\circ} 00^{\prime} \mathrm{W}$ and $918 \mathrm{~m}$ altitude, and with Köppen classification of Cwa) in two rabbit houses: one with ridge vent (WRV) and the other without ridge vent (NRV). This study was carried out at the end of the summer period of 2016 and no animals were housed in the animal facilities.

The rabbit houses had $6.20 \mathrm{~m}$ width, $9.60 \mathrm{~m}$ length, $3.40 \mathrm{~m}$ ceiling height, walls $0.80 \mathrm{~m}$ height, $1.15 \mathrm{~m}$ eaves, clay roof tiles, and inclination of $30^{\circ}$. The rabbit houses were oriented in the direction magnetic East-West. The rabbit houses had concrete floor and two cemented drainage ditches with dimensions of $1.50 \times 6.00 \mathrm{~m}$ and $0.80 \mathrm{~m}$ depth. The house WRV is structurally similar to the house NRV, but with a ridge vent assisting in air renovation and in ventilation of inner environment (Figure 1).

In order to characterize the thermal environment inside the house, measurements of dry-bulb temperature $\left(\mathrm{t}_{\mathrm{db}},{ }^{\circ} \mathrm{C}\right)$, relative humidity ( $\mathrm{RH}, \%)$ and wind speed (WS, $\mathrm{m} \mathrm{s}^{-1}$ ) at $1.0 \mathrm{~m}$ height inside the house, three times a day, at 7:00 a.m., 12:00 a.m. and 5:00 p.m. were performed.

The climatic variables $\left(\mathrm{t}_{\mathrm{db}}\right.$ and $\left.\mathrm{RH}\right)$ were evaluated using digital thermo hygrometer (INSTRUTEMP ${ }^{\oplus}$, mod. ITWH1280 , precision of $\pm 0.1^{\circ} \mathrm{C}$ and $\left.1.0 \%\right)$. The WS was measured using a digital anemometer (Kerstrel 4000, precision of \pm
A.

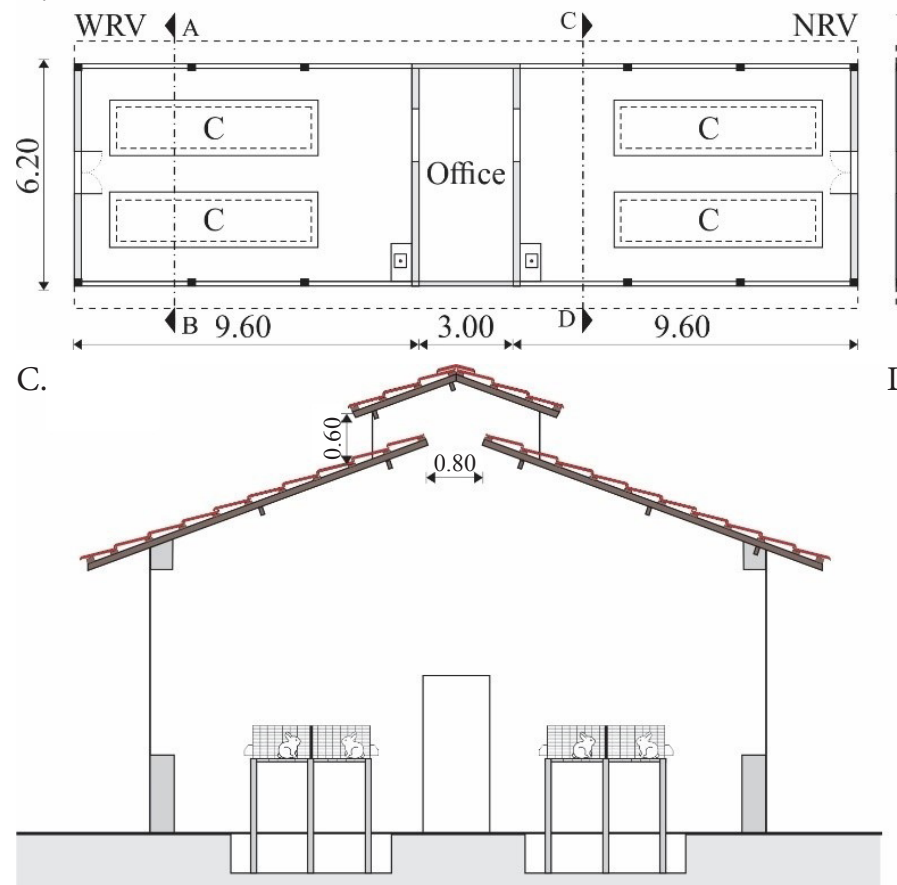

B.

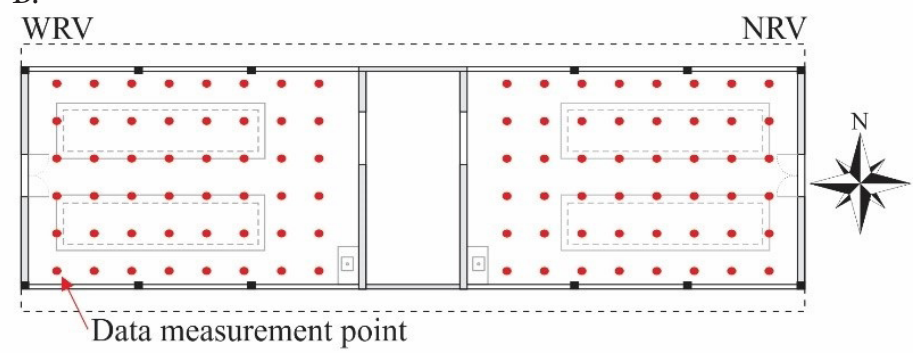

D.

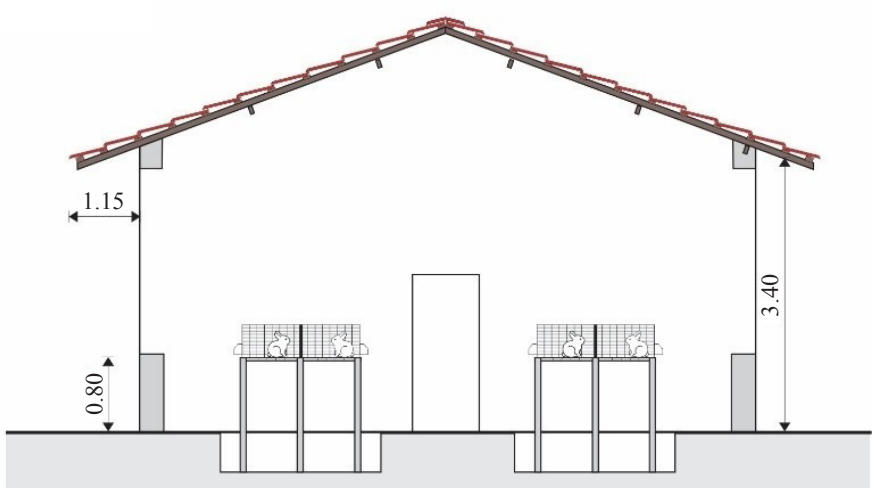

Figure 1. A - Floor plan of houses with vent ridge (WRV) and without ridge vent (NRV), B - Plant of position of measurement points with ridge vent (WRV) and without ridge vent (NRV), $C$ and $D$ - cuts $A B$ and $C D$ of house section with ridge vent (WRV) and without vent (NRV), respectively 
3.0\%). Inside each rabbit house, the sensors were positioned forming a $1.0 \times 1.0 \mathrm{~m}$ grid, totaling 48 data points in each house.

Subsequently, the $\mathrm{H}$ was calculated through the Eq. 1 developed by Albright (1990).

$$
\mathrm{H}=1.006 \mathrm{t}_{\mathrm{db}}+\mathrm{W}\left(2501+1.805 \mathrm{t}_{\mathrm{db}}\right)
$$

where:

$\mathrm{H}$ - enthalpy, in $\mathrm{kJ} \mathrm{kg}^{-1}$ dry air;

$\mathrm{t}_{\mathrm{db}}$ - dry-bulb temperature, in ${ }^{\circ} \mathrm{C}$; and,

W - mixture ratio, in $\mathrm{kg} \mathrm{kg}^{-1}$ dry air calculated by the Eq. 2.

$$
\mathrm{W}=\frac{(0.622 \mathrm{ea})}{\left(\mathrm{P}_{\mathrm{atm}}-\mathrm{ea}\right)}
$$

where:

ea - water vapor pressure, in $\mathrm{kPa}$; and,

$\mathrm{P}_{\mathrm{atm}}$ - atmospheric pressure, in $\mathrm{kPa}$.

After the results obtained from calculation of the $\mathrm{H}$ of rabbit houses, the spatial variability was analyzed using semivariogram fitting and interpolation by ordinary kriging. The classic semivariogram was estimated by the Eq. 3:

$$
\hat{\gamma}(h)=\frac{1}{2 N(h)} \sum_{i=1}^{N(h)}\left[Z\left(x_{i}\right)-Z\left(x_{i}+h\right)\right]^{2}
$$

where:

$\hat{\gamma}(\mathrm{h})$ - semivariance;

$\mathrm{N}(\mathrm{h})$ number of experimental pairs of observations $\mathrm{Z}\left(\mathrm{X}_{\mathrm{i}}\right)$; and,

$\mathrm{Z}_{(\mathrm{xi}+\mathrm{h})}$ - at locations $\mathrm{x}_{\mathrm{i}}+\mathrm{h}$ separated by the lag distance $\mathrm{h}$.

The semivariogram was fitted by the residual maximum likelihood (REML) method, which generally results in less biased estimates for small samplings (Marchant \& Lark, 2007).

The mathematical model used to perform the semivariogram fitting was spherical, which is widely used in geostatistical studies, since they are referenced in geostatistics as transitive models (models with sill $\mathrm{C}_{0}+\mathrm{C}_{1}$ ). The selection of the spherical model is justified because it is the one that best adapted to the fits in studies in the environmental variables in facilities for animals (Ponciano et al., 2013; Gonçalves et al., 2016; Ribeiro et al., 2016). From the fit of a mathematical model to the calculated values of $\gamma(\mathrm{h})$, the following coefficients of the theoretical model for the semivariogram are calculated: nugget effect $\left(\mathrm{C}_{0}\right)$, sill $\left(\mathrm{C}_{0}+\mathrm{C}_{1}\right)$ and range (a). In addition, the spatial dependence degree (SDD) of the variables was analyzed according to the classification proposed by Cambardella et al. (1994). The validation was used to determine the mean error, standard deviation of the mean error, reduced mean error and standard deviation of the reduced mean error. The validation was performed to verify if the fits in the semivariograms met the requirements and if they were satisfactory.
After the semivariogram fitting, the data were interpolated by ordinary kriging in order to allow visualizing spatial distribution patterns of the $\mathrm{H}$ inside rabbit houses.

The geostatistical analysis was performed using the $\mathrm{R}$ computer system (R Development Core Team, 2017), through the geoR package (Ribeiro Junior \& Diggler, 2001).

\section{Results AND Discussion}

It is possible to observe in Figure 2 the $H$ values inside the rabbit house NRV at three times during eight analyzed days and the comfort limits of $\mathrm{H}$ for rabbits, which are indicated in the figure by dashed lines, calculated according to the recommendations of Ferreira et al. (2012) and Jaruche et al. (2012).

It can be observed by Figure 2 that the $H$ values in the house NRV ranged from 47.7 to $96.3 \mathrm{~kJ} \mathrm{~kg}^{-1}$ dry air in relation to the three analyzed times. According to Jaruche et al. (2012), $\mathrm{t}_{\mathrm{db}}$ of comfort for rabbits with adult age ranged from 15 to $25^{\circ} \mathrm{C}$ and RH was 60 to $70 \%$, according to Ferreira et al. (2012). By using the

A.

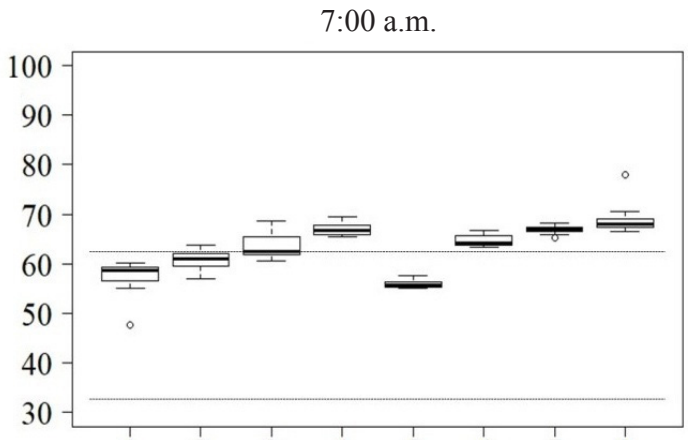

B.

12:00 a.m.
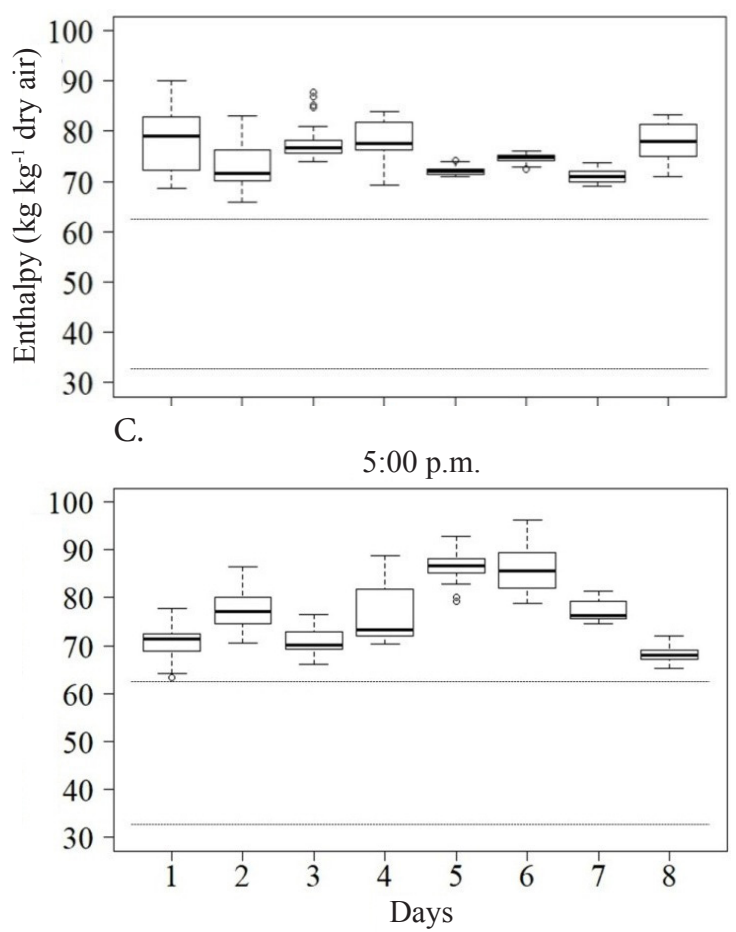

Figure 2. Boxplot of $\mathrm{H} ; \mathrm{A}$ - at 7:00 a.m., B - 12:00 a.m., C - 5:00 p.m., during eight experimental days inside the house with ridge vent (WRV), and the $\mathrm{H}$ of comfort (dashed line) 
ideal $\mathrm{t}_{\mathrm{db}}$ and $\mathrm{RH}$ values applied by these authors in the equation proposed by Albright (1990) to calculate $\mathrm{H}$, the ideal $\mathrm{H}$ value for rabbit production would range from 31.1 to $62.6 \mathrm{~kJ} \mathrm{~kg}^{-1}$ dry air, which are indicated in the figures by dashed lines.

It is possible to observe in Figure 3 the $H$ values inside the house WRV at three times during the eight analyzed days and the comfort limits of $\mathrm{H}$ for rabbits calculated according to the recommendations of Ferreira et al. (2012) and Jaruche et al. (2012) indicated by dashed lines. It can be observed that during the experimental period, the $\mathrm{H}$ values ranged from 51.6 to $89.5 \mathrm{~kJ} \mathrm{~kg}^{-1}$ dry air in this house.

Both in rabbit house NRV (Figure 2) and in rabbit house WRV (Figure 3), within the analyzed times, the time 7:00 a.m. (Figures $2 \mathrm{~A}$ and $3 \mathrm{~A}$, respectively) showed milder environmental conditions, while 12:00 a.m. (Figures $2 \mathrm{~B}$ and $3 \mathrm{~B}$, respectively) and 5:00 p.m. (Figures $2 \mathrm{C}$ and $3 \mathrm{C}$, respectively) showed higher values of $\mathrm{H}$. At 12:00 a.m. and 5:00 p.m., the $\mathrm{H}$ values were outside the comfort interval for rabbit breeding (dashed lines) throughout the experimental period, which can be harmful to the rabbit breeding. According to Baracho et al. (2013), the animals achieve their optimum productivity when they are maintained in thermoneutral environment, i.e.,

A.

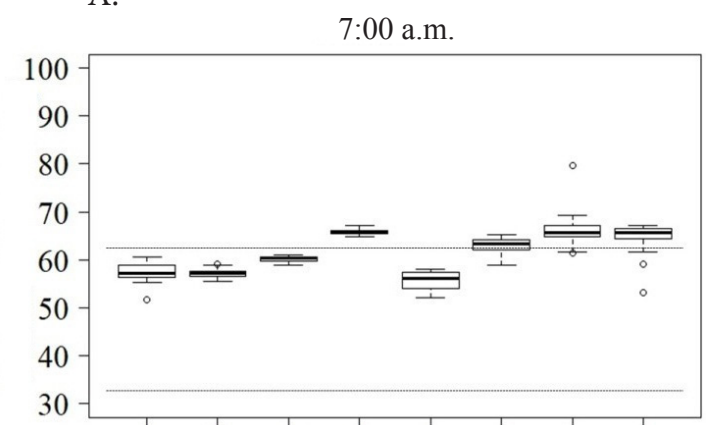

B.

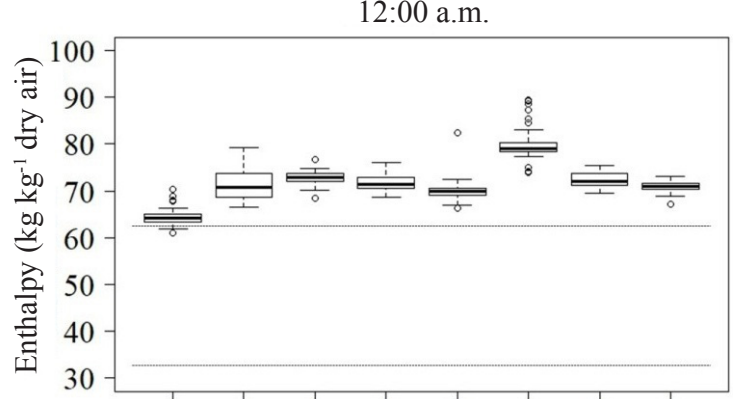

C.

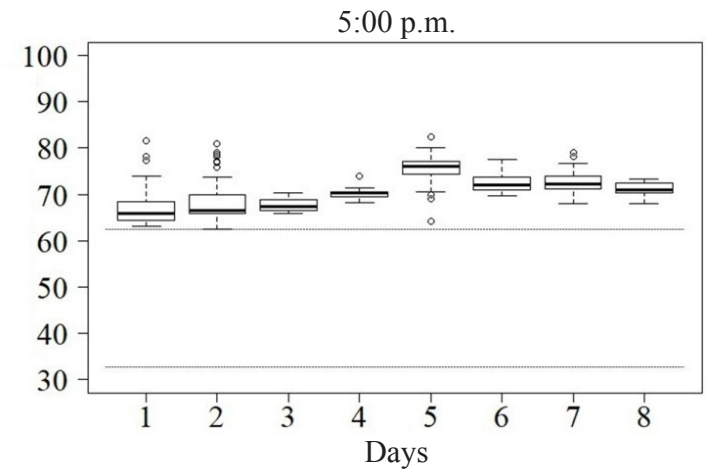

Figure 3. Boxplot of enthalpy; A - at 7:00 a.m., B - at 12:00 a.m., $C-$ at 5:00 p.m., during eight experimental days inside the house without ridge vent (NRV), and the enthalpy of comfort (dashed line) when the feed energy is not diverted to compensate thermal deviations from the thermoneutral range in order to eliminate or maintain its body temperature. Thus, when adult rabbits are subjected to thermal conditions other than their thermal comfort, they can harm the animal's productive performance.

Based on Figures 2 and 3, a variability was verified in the $\mathrm{H}$ data over the analyzed time, but only this exploratory analysis would not allow analyzing the homogeneity of spatial distribution of $\mathrm{H}$ inside rabbit houses. In this way, the geostatistical analysis of $\mathrm{H}$ was used to evaluate this variability in the three times evaluated in house NRV and in house WRV (Table 1). It was verified that there was spatial dependence in both facilities during all the days in the different analyzed times.

When evaluating the data obtained during the experiment in rabbits' facilities NRV and WRV (Table 1), it was verified that both houses show spatial dependence daily in the different analyzed times.

It can be observed in Table 1 the nugget effect $\left(\mathrm{C}_{0}\right)$ values of two houses (NRV and WRV), identifying the unexplained variability and considering the sampling distance (Mcbratney \& Webster, 1986). In order to compare the spatial dependence degree (SDD), the nugget effect is expressed as sill ratio $\left(\mathrm{C}_{0}+\right.$ $\mathrm{C}_{1}$ ) because there is a difficulty in quantifying the individual contribution of errors (Trangmar et al., 1985).

Considering the classification of Cambardella et al. (1994) and observing the data for the NRV, the spatial dependence degree (SDD) was moderate only on $1^{\text {st }}$ and $8^{\text {th }}$ day at 7:00 a.m. and 5:00 p.m., on $2^{\text {nd }}$ day at 7:00 a.m.. On the other days, SDD was strong. By analyzing the range values (a) for determination of spatial dependence threshold, important differences were observed, which showed that on $3^{\text {rd }}$ day, at 5:00 p.m., the minimum range value was $0.92 \mathrm{~m}$; and, on $7^{\text {th }}$ day, at 7:00 a.m., the maximum range value was $5.67 \mathrm{~m}$ (Table 1).

When analyzing the results of WRV (Table 1), it was observed that on $4^{\text {th }}$ day, at 5:00 p.m., SDD was considered weak and, on $8^{\text {th }}$ day, at 7:00 a.m., moderate SDD according to classification of Cambardella et al. (1994). The maximum and minimum range values of the house WRV were 6.77 and $0.92 \mathrm{~m}$, observed at 7:00 a.m. and 5:00 p.m. on $8^{\text {th }}$ day, respectively.

Using the values estimated by kriging, it was possible to generate isocolor maps with the spatialization of $\mathrm{H}$ on different days and times in houses NRV and WRV (Figures 4 and 5, respectively).

By analyzing the isocolor maps of the spatial distribution, it was possible to observe the existence of spatial variability of $\mathrm{H}$ during all the times for each analyzed day in house NRV (Figure 4) and in house WRV (Figure 5). Regions with lower $H$ values are characterized by bluish and greenish tones, and regions with higher $\mathrm{H}$ values are represented by colors ranging from yellow to reddish tones.

When observing the rabbit house NRV maps (Figure 4 ), it is evident that there was a great spatial variation of $\mathrm{H}$ between days and between the evaluated times, indicating that animals raised in this environment would be subjected to different environmental conditions within a same facility. It is worth highlighting the great variability of $\mathrm{H}$ throughout the day, because $\mathrm{H}$ values in this house were always lower in the morning and much higher in the afternoon. 
Table 1. Method REML, model spherical and estimated parameters of experimental semivariograms for the enthalpy inside rabbit house NRV and WRV during the eight days analyzed at 7:00 a.m., 12:00 a.m. and 5:00 p.m.

\begin{tabular}{|c|c|c|c|c|c|c|c|c|c|c|c|c|}
\hline Days & $\begin{array}{l}\text { Rabbit } \\
\text { house }\end{array}$ & Hour & $\mathbf{C}_{0}$ & $\mathbf{C}_{1}$ & $C_{0}+C_{1}$ & $\underset{(\mathrm{m})}{\mathrm{A}}$ & & & ME & SDME & RE & SDRE \\
\hline \multirow{3}{*}{1} & & 7 & 2.26 & 3.09 & 5.35 & 5.64 & 42.21 & Moderate & 0.00 & 1.91 & 0.00 & 1.02 \\
\hline & NRV & 12 & 0.00 & 33.90 & 33.90 & 0.97 & 0.00 & Strong & 0.00 & 5.95 & 0.00 & 1.01 \\
\hline & & 5 & 6.02 & 4.74 & 10.76 & 3.09 & 55.96 & Moderate & -0.01 & 3.05 & 0.00 & 1.01 \\
\hline \multirow{3}{*}{2} & & 7 & 6.02 & 4.74 & 10.76 & 3.09 & 55.96 & Moderate & -0.01 & 0.90 & 0.00 & 0.29 \\
\hline & NRV & 12 & 0.00 & 18.76 & 18.76 & 5.31 & 0.00 & Strong & -0.05 & 1.79 & -0.01 & 0.82 \\
\hline & & 5 & 0.00 & 12.94 & 12.94 & 3.18 & 0.00 & Strong & -0.03 & 1.95 & -0.01 & 0.85 \\
\hline \multirow{3}{*}{3} & & 7 & 0.00 & 2.91 & 2.91 & 5.66 & 0.00 & Strong & -0.02 & 0.72 & -0.01 & 0.85 \\
\hline & NRV & 12 & 0.00 & 24.56 & 24.56 & 5.58 & 0.00 & Strong & 0.03 & 2.39 & 0.01 & 0.98 \\
\hline & & 5 & 0.00 & 7.52 & 7.52 & 0.92 & 0.00 & Strong & 0.00 & 2.80 & 0.00 & 1.01 \\
\hline \multirow{3}{*}{4} & & 7 & 0.00 & 2.05 & 2.05 & 5.12 & 0.00 & Strong & 0.01 & 0.70 & 0.01 & 0.98 \\
\hline & NRV & 12 & 0.00 & 22.24 & 22.24 & 5.43 & 0.00 & Strong & -0.03 & 2.47 & -0.01 & 1.02 \\
\hline & & 5 & 0.00 & 21.98 & 21.98 & 4.06 & 0.00 & Strong & -0.04 & 2.38 & -0.01 & 0.90 \\
\hline \multirow{3}{*}{5} & & 7 & 0.00 & 0.78 & 0.78 & 4.81 & 0.00 & Strong & 0.01 & 0.48 & 0.01 & 1.01 \\
\hline & NRV & 12 & 0.16 & 0.97 & 1.13 & 4.35 & 14.29 & Strong & -0.01 & 0.70 & 0.00 & 1.01 \\
\hline & & 5 & 0.00 & 7.04 & 7.04 & 5.42 & 0.00 & Strong & 0.01 & 1.12 & 0.00 & 0.83 \\
\hline \multirow{3}{*}{6} & & 7 & 0.00 & 0.69 & 0.69 & 3.95 & 0.00 & Strong & 0.00 & 0.39 & 0.00 & 0.83 \\
\hline & NRV & 12 & 0.00 & 0.87 & 0.87 & 4.77 & 0.00 & Strong & -0.01 & 0.46 & -0.01 & 0.93 \\
\hline & & 5 & 0.00 & 14.82 & 14.82 & 3.98 & 0.00 & Strong & 0.02 & 1.71 & 0.01 & 0.75 \\
\hline \multirow{3}{*}{7} & & 7 & 0.06 & 0.37 & 0.42 & 5.67 & 13.58 & Strong & -0.01 & 0.42 & -0.01 & 1.04 \\
\hline & NRV & 12 & 0.00 & 1.49 & 1.49 & 2.67 & 0.00 & Strong & 0.00 & 0.84 & 0.00 & 0.99 \\
\hline & & 5 & 0.00 & 5.42 & 5.42 & 5.65 & 0.00 & Strong & 0.00 & 1.04 & 0.00 & 0.91 \\
\hline \multirow{3}{*}{8} & & 7 & 1.49 & 1.69 & 3.18 & 2.27 & 46.79 & Moderate & 0.00 & 1.72 & 0.00 & 1.02 \\
\hline & NRV & 12 & 0.00 & 13.29 & 13.29 & 0.98 & 0.00 & Strong & 0.00 & 3.72 & 0.00 & 1.01 \\
\hline & & 5 & 0.72 & 1.18 & 1.90 & 4.38 & 37.78 & Moderate & 0.00 & 1.08 & 0.00 & 1.00 \\
\hline \multirow{3}{*}{1} & & 7 & 0.00 & 2.62 & 2.62 & 0.94 & 0.00 & Strong & 0.00 & 1.65 & 0.00 & 1.01 \\
\hline & WRV & 12 & 0.00 & 3.27 & 3.27 & 1.76 & 0.00 & Strong & 0.00 & 1.56 & 0.00 & 0.95 \\
\hline & & 5 & 0.00 & 17.43 & 17.43 & 3.49 & 0.00 & Strong & 0.05 & 2.46 & 0.01 & 0.93 \\
\hline \multirow{3}{*}{2} & & 7 & 0.00 & 0.55 & 0.55 & 4.71 & 0.00 & Strong & 0.01 & 0.36 & 0.01 & 0.89 \\
\hline & WRV & 12 & 0.00 & 7.64 & 7.64 & 2.89 & 0.00 & Strong & 0.00 & 1.49 & 0.00 & 0.80 \\
\hline & & 5 & 0.00 & 13.29 & 13.29 & 5.38 & 0.00 & Strong & 0.00 & 1.41 & 0.00 & 0.78 \\
\hline \multirow{3}{*}{3} & & 7 & 0.03 & 0.43 & 0.45 & 3.97 & 5.52 & Strong & -0.01 & 0.44 & -0.01 & 1.03 \\
\hline & WRV & 12 & 0.00 & 2.17 & 2.17 & 4.30 & 0.00 & Strong & -0.02 & 0.74 & -0.01 & 0.92 \\
\hline & & 5 & 0.00 & 1.82 & 1.82 & 0.98 & 0.00 & Strong & 0.00 & 1.38 & 0.00 & 1.01 \\
\hline \multirow{3}{*}{4} & & 7 & 0.00 & 0.30 & 0.30 & 0.98 & 0.00 & Strong & 0.00 & 0.56 & 0.00 & 1.01 \\
\hline & WRV & 12 & 0.00 & 2.04 & 2.04 & 3.02 & 0.00 & Strong & -0.01 & 0.81 & 0.00 & 0.85 \\
\hline & & 5 & 0.89 & 0.18 & 1.07 & 4.83 & 83.27 & Weak & 0.00 & 1.03 & 0.00 & 1.01 \\
\hline \multirow{3}{*}{5} & & 7 & 0.00 & 3.29 & 3.29 & 0.98 & 0.00 & Strong & 0.00 & 1.85 & 0.00 & 1.01 \\
\hline & WRV & 12 & 0.00 & 5.31 & 5.31 & 0.96 & 0.00 & Strong & 0.00 & 2.35 & 0.00 & 1.01 \\
\hline & & 5 & 0.00 & 9.48 & 9.48 & 0.96 & 0.00 & Strong & 0.00 & 3.14 & 0.00 & 1.01 \\
\hline \multirow{3}{*}{6} & & 7 & 0.00 & 3.40 & 3.40 & 0.95 & 0.00 & Strong & 0.00 & 1.88 & 0.00 & 1.01 \\
\hline & WRV & 12 & 0.00 & 11.45 & 11.45 & 0.97 & 0.00 & Strong & 0.00 & 3.46 & 0.00 & 1.01 \\
\hline & & 5 & 0.00 & 5.91 & 5.91 & 0.98 & 0.00 & Strong & 0.00 & 2.48 & 0.00 & 1.01 \\
\hline \multirow{3}{*}{7} & & 7 & 1.06 & 11.98 & 13.04 & 5.51 & 8.16 & Strong & 0.00 & 2.14 & 0.00 & 1.03 \\
\hline & WRV & 12 & 0.00 & 2.19 & 2.19 & 6.27 & 0.00 & Strong & -0.01 & 0.59 & 0.00 & 0.89 \\
\hline & & 5 & 0.00 & 6.17 & 6.17 & 0.98 & 0.00 & Strong & 0.00 & 2.54 & 0.00 & 1.01 \\
\hline \multirow{3}{*}{8} & & 7 & 4.74 & 2.32 & 7.06 & 6.77 & 67.10 & Moderate & -0.01 & 2.40 & 0.00 & 1.01 \\
\hline & WRV & 12 & 0.00 & 2.21 & 2.21 & 4.93 & 0.00 & Strong & -0.01 & 0.63 & -0.01 & 0.81 \\
\hline & & 5 & 0.00 & 2.25 & 2.25 & 0.92 & 0.00 & Strong & 0.00 & 1.53 & 0.00 & 1.01 \\
\hline
\end{tabular}

$\mathrm{C}_{0}$ - Pepita Effect; $\mathrm{C}_{1}$ - Contribution; $\mathrm{C}_{0}+\mathrm{C}_{1}$ - Porch; A - Range; SDD - Degree of Spatial Dependence; ME - Medium error; SDME - Standard deviation of mean error; RE - Reduced mean error; SDRE - Standard deviation of reduced mean error

In addition, only at 7 a.m., the lowest values of $\mathrm{H}$ were observed inside the rabbit house NRV, but at this time, only days 1, 2 and 3 (Figures 4A, D and G, respectively) the $\mathrm{H}$ might be considered as comfort (31.1 to $62.6 \mathrm{~kJ} \mathrm{~kg}^{-1}$ dry air). These comfort values of $\mathrm{H}$ for rabbits were calculated through Albright (1990) equation (Eq. 1) as a function of the parameters of $t_{d b}$ and RH proposed by Ferreira et al. (2012) and Jaruche et al. (2012), respectively. At 12:00 a.m. and 5:00 p.m., the house's $\mathrm{H}$ was always outside the range considered as ideal, possibly due to the high $\mathrm{t}_{\mathrm{db}}$ that occurred on those days and the low $\mathrm{RH}$ values that occurred during the experimental period, which influenced the values of $\mathrm{H}$ from inside. Regarding the thermal comfort and welfare of rabbits, it should be emphasized that these animals are more sensitive to heat than to cold, therefore, sudden changes in thermal conditions are more harmful than a gradual change in temperature outside the comfort zone (Ferreira et al., 2012).

When the spatial distribution of $\mathrm{H}$ inside the house WRV (Figure 5) is verified, it is also possible to observe a great heterogeneity between the studied days and times, but smaller than in the house NRV (Figure 4). Although only days 1, 2, 3 and 5 in the 7:00 a.m. period (Figures 5A, B, C and E, respectively) show $\mathrm{H}$ values within the ideal range (31.1 to $62.6 \mathrm{~kJ} \mathrm{~kg}^{-1}$ dry air), it is observed on other days and times that the variation of $\mathrm{H}$ values was lower than in house NRV, guaranteeing milder $\mathrm{H}$ values inside the rabbit house. This 


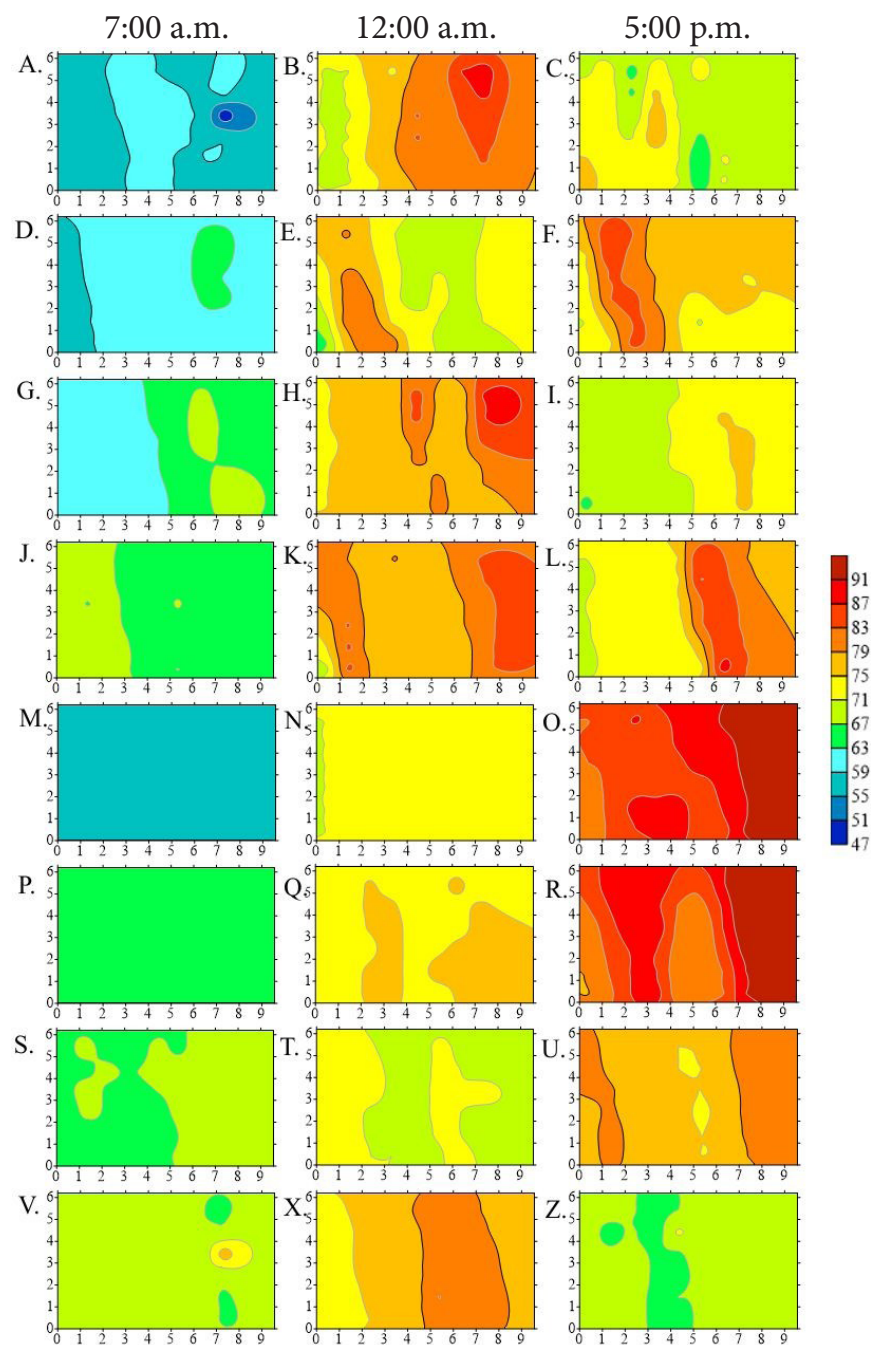

Figure 4. Spatial distribution of enthalpy $\left(\mathrm{kJ} \mathrm{kg}^{-1} \mathrm{dry}\right.$ air) in house NRV on $A, B$ and $C-1^{\text {st }}, D, E$ and $F-2^{\text {nd }}, G, H$ and $I-3^{\text {rd }}, J, K$ and $\mathrm{L}-4^{\text {th }}, \mathrm{M}, \mathrm{N}$ and $\mathrm{O}-5^{\text {th }}, \mathrm{P}, \mathrm{Q}$ and $\mathrm{R}-6^{\text {th }}, \mathrm{S}, \mathrm{T}$ and $\mathrm{U}-7^{\text {th }}$ and $\mathrm{V}, \mathrm{X}$ and $Z-8^{\text {th }}$ days at 7:00 a.m., 12:00 a.m. and 5:00 p.m. respectively

fact is evidenced by the greenish and yellowish colors in the house WRV (Figure 5), whereas the house NRV maps (Figure 4) are orange and reddish, representing more critical $H$ values and hence causing greater discomfort for animals subjected to this situation.

In constructions with a ridge vent, such as the case of Figure 5, Mazon et al. (2006) explain that the natural ventilation of the house is responsible for regulating the internal climate of a building through an air exchange controlled by openings. In these facilities, the natural driving forces generate the stack effect, which occurs due to the temperature difference between the external air and the air inside the built environment and by differences in pressure caused by the wind. During the experimental period, WS inside the facility was virtually nonexistent, reaching a maximum of $0.1 \mathrm{~m} \mathrm{~s}^{-1}$. Thereby, Mazon et al. (2006) explain that in situations without wind, the stack effect, caused by the ridge vent, becomes the sole responsible for renewal the air in buildings and represents the simplest situation of natural ventilation. Such situation may explain the more homogeneous and milder environmental conditions of the house WRV in relation to the house NRV. The same results were found by Gonçalves et al. (2016) when they compared
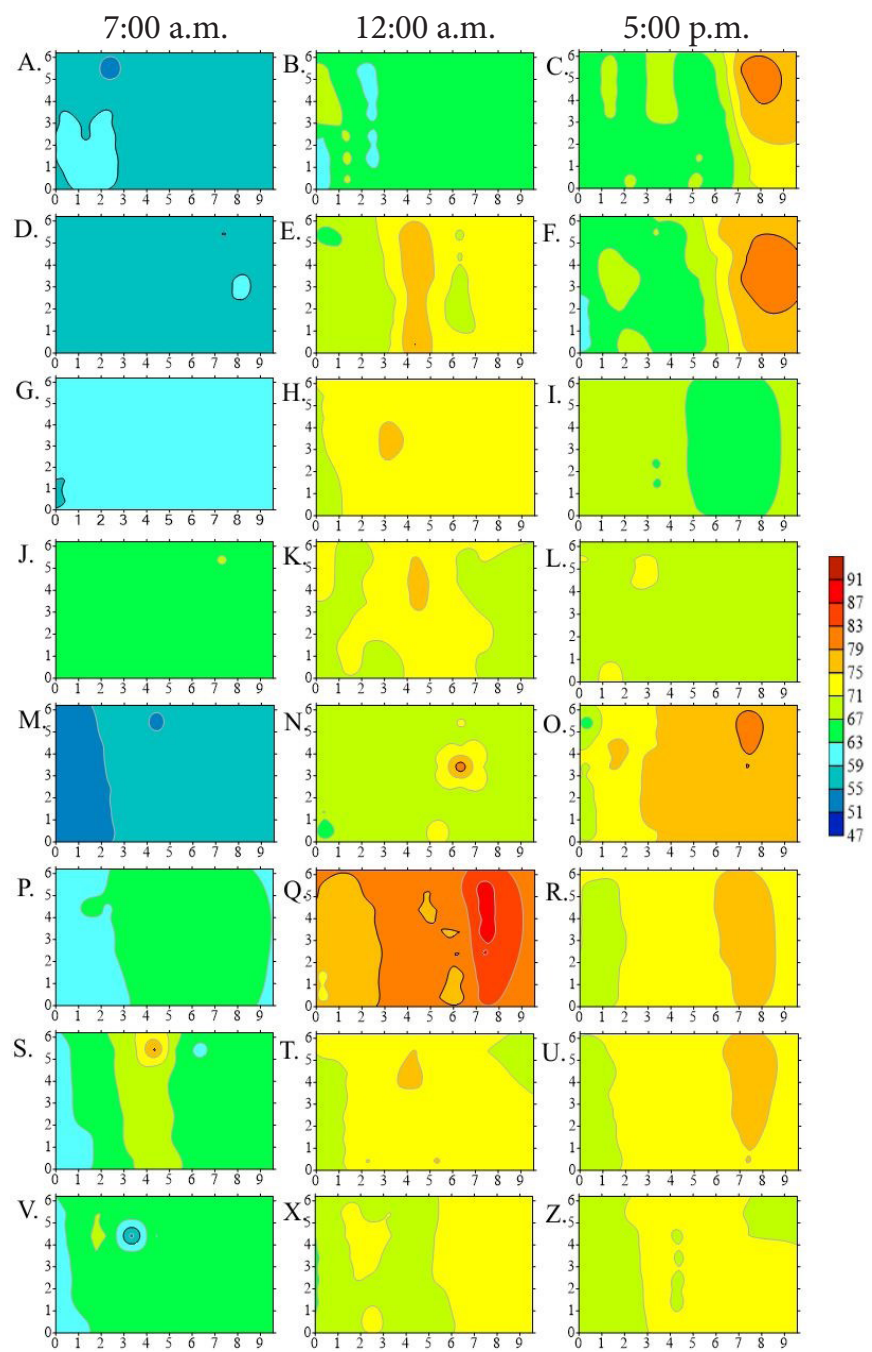

Figure 5. Spatial distribution of enthalpy ( $\mathrm{kJ} \mathrm{kg}^{-1} \mathrm{dry}$ air) in house WRV on $A, B$ and $C-1^{\text {st }}, D, E$ and $F-2^{\text {nd }}, G, H$ and $I-3^{\text {rd }}, J, K$ and $L-4^{\text {th }}, M, N$ and $O-5^{\text {th }}, P, Q$ and $R-6^{\text {th }}, S, T$ and $U-7^{\text {th }}$ and $V, X$ and $Z-8^{\text {th }}$ days at 7:00 a.m., 12:00 a.m. and 5:00 p.m. respectively

the $t_{d b}$ of facilities for cows with and without ridge vent. These authors affirm that the thermal conditions in facilities with ridge vent is better than in facilities without and the use of this typological modification is highly recommendable for proper ventilation, since it allows a continuous renewing of air, resulting in an adequate environment for the animals.

According to Ferreira et al. (2012), zootechnical facilities must be constructed with the purpose of reducing the effect of the environment on the productive performance of rabbits, which hence will increase yield, thus avoiding reproductive problems and financial losses caused by the thermal discomfort of these animals.

Through the isocolor maps, it can also be noted that during the whole experimental period, the eastern side of both the house NRV (Figure 4) and the house WRV (Figure 5) showed higher $\mathrm{H}$ values than the rest of the rabbit house, especially at 5:00 p.m. This may be because there was a high incidence of solar radiation in this part of house during most of the day at this time of year, which caused a greater heating of the external walls and, consequently, this house region. It is also evident that despite occurring in both houses, the eastern side of the house NRV (Figure 4) always shows higher values 
of $\mathrm{H}$, whereas more discrete in the house WRV (Figure 5). According to Yanagi Junior et al. (2011), a homogeneity of variables inside the facility is expected inside a production environment; otherwise, there may be an imbalance between the thermal conditions that the animals are subjected to and the batch uniformity.

According to Ondruska et al. (2011), for the practice of intensive rabbit breeding, it is necessary that the facilities and equipment be adequate to provide a greater comfort to the animal, besides favoring the management of the breeding, providing greater financial gain for the producer. According to Ondruska et al. (2011) and Jaruche et al. (2012), when rabbits are exposed to different environmental conditions from their thermoneutral zone, this may cause imbalance in their body temperatures and hence adversely affect growth and reproduction. In addition, animals reared under stress can suffer from eating disorders, weight gain, feed conversion, water consumption, changes in blood parameters, enzymatic and hormonal reactions, besides imbalance of proteins, energy and minerals.

In this sense, in an attempt to mitigate the harmful effects of environmental stress, similar studies that evaluates the thermal conditions of animals due to the constructive characteristics of the facility become important for the development of specific technologies for hot climate regions, producing information that guides the ambience activities of rabbits.

\section{Conclusions}

1. It was observed that there was heterogeneity of the spatial distribution of these parameters in houses throughout the evaluated times and days.

2. The ridge vent in rabbit house aided to obtain a more favorable internal environment for rabbit breeding, to provide an internal environment with more comfortable enthalpy values, as well as a greater spatial homogeneity of values of this variable in relation to the house without ridge vent.

\section{Literature Cited}

Albright, L. D. Environment control for animals and plants. 1.ed. St Joseph: American Society of Agricultural Engineers, 1990. 453p.

Baracho, M. S.; Cassiano, J. de A.; Nääs, I. de A.; Tonon, G. S.; Garcia, R. G.; Royer, A. F. B.; Moura, D. J. de; Santana, M. R. de. Ambiente interno em galpões de frango de corte com cama nova e reutilizada. Revista Agrarian, v.6, p.473-478, 2013.

Cambardella, C. A.; Moorman, T. B.; Parkin, T. B.; Karlen, D. L.; Novak, J. M.; Turco, R. F.; Konopka, A. E. Field-scale variability of soil properties in central Iowa soils. Soil Science Society of America Journal, v.58, p.1501-1511, 1994. http://dx.doi. org/10.2136/sssaj1994.03615995005800050033x.

FAOSTAT - Food and Agriculture Organization of the United Nations. Corporate statistical database, 2017. Available on: <http://www. fao.org/faostat/en/\#data/QL>. Access on: May 2017.

Ferreira, W. M.; Machado, L. C.; Jaruche, Y. de G.; Carvalho, G. G. de; Oliveira, C. E. A. de; Souza, J. A. S.; Caríssimo, A. P. G. (eds.). Manual prático de cunicultura. Bambuí: Associação Brasileira de Cunicultura, 2012. 75p.
Gonçalves, I. C. M.; Turco, S. H. N.; Ramos, C. M. C. Variabilidade espacial da temperatura do ar de um free-stall na região semiárida nordestina do Brasil. Revista Brasileira de Engenharia Agrícola e Ambiental, v.20, p.67-71, 2016. http://dx.doi.org/10.1590/18071929/agriambi.v20n1p67-71.

Jaruche, Y. G.; Faria Filho, D. E. F.; Dias, A. N.; Fernandes, D. P.; Ribeiro, H. O. C.; Siqueira, A. A.; Sima, P. S.; Ornelas, O. T. C.; Cruz, L. J.; Caixeta, V.; Barbosa, P. M. Efeito da densidade de alojamento sobre a homeostase térmica em coelhas em crescimento mantidas em diferentes temperaturas. Revista Brasileira de Cunicultura, v.1, p.1-42, 2012.

Machado, L. C. Pesquisas de preferência, divulgação da atividade de cunicultura e mercado pet cunícula brasileiro. Revista Brasileira de Cunicultura, v.8, p.1-12, 2015.

Marchant, B. P.; Lark, R. M. Robust estimation of the variogram by residual maximum likelihood. Geoderma, v.140, p.62-72, 2007. http://dx.doi.org/10.1016/j.geoderma.2007.03.005.

Mazon, A. A. O.; Silva, R. G. O.; Souza, H. A. de. Ventilação natural em galpões: $\mathrm{O}$ uso de lanternins nas coberturas. Revista Escola de Minas, v.59, p.179-184, 2006. http://dx.doi.org/10.1590/S037044672006000200007.

McBratney, A. B.; Webster, R. Choosing functions for semivariograms of soil properties and fitting them to sampling estimates. Journal Soil Science, v.3, p.617-639, 1986. http://dx.doi. org/10.1111/j.1365-2389.1986.tb00392.x.

Ondruska, L.; Rafay, J.; Okab, A. B.; Ayoub, M. A.; Al-Haidary, A. A.; Samara, E. M.; Parkanyi, V.; Chrastinova, L.; Jurcik, R.; Massanyi, P.; Lukac, N.; Supuka, P. Influence of elevated ambient temperature upon some physiological measurements of New Zealand white rabbits. Veterinarni Medicina, v.56, p.180-186, 2011.

Ponciano, P. F.; Yanagi Junior, T.; Ferraz, G. A. e S.; Scalon, J. D.; Schiassi, L. Spatial variability of air dry bulb temperature and black globe humidity index in a broiler house during the heating phase. Engenharia Agrícola, v.33, p.433-444, 2013. http://dx.doi. org/10.1590/S0100-69162013000300001.

R Development Core Team. R: A language and environment for statistical computing. Vienna: R Foundation for Statistical Computing, 2017. Available on: <http://www.R-project.org/>. Access on: Set. 2017.

Ribeiro Junior, P. J.; Diggle, P. J. GeoR: A package from geostatistical analysis. R-News, v.1, p.15-18, 2001.

Ribeiro, P. A. P.; Yanagi Junior, T.; Oliveira, D. D. de; Ferraz, G. A. e S.; Lourençoni, D. Análise geoestatística das iluminâncias em avíários para poedeiras equipados com lâmpadas fluorescentes compactas e de led. Engenharia Agrícola, v.36, p.962-971, 2016. http://dx.doi. org/10.1590/1809-4430-eng.agric.v36n6p962-971/2016

Rodrigues, V. C.; Silva, I. J. O.; Vieira, F. M. C.; Nascimento, S. T. A correct enthalpy relationship as thermal comfort index for livestock. International Journal Biometeorology, v.55, p. 455-459, 2010. https://doi.org/10.1007/s00484-010-0344-y

Trangmar, B. B.; Yost, R. S.; Wade, M. K.; Uehara, G. Applications of geostatistics to spatial studies of soil properties. Advances in Agronomy, v.38, p.45-94, 1985. https://doi.org/10.1016/S00652113(08)60673-2

Yanagi Junior, T.; Amaral, A. G. do; Teixeira, V. H.; Lima, R. R. de. Caracterização espacial do ambiente termoacústico e de iluminância em galpão comercial para criação de frangos de corte. Engenharia Agrícola, v.31, p.1-12, 2011. http://dx.doi. org/10.1590/S0100-69162011000100001 